\title{
Where Lean May Shake: Challenges to Casualisation in the Indian Auto Industry
}

\author{
Lorenza Monaco, University of Johannesburg, South Africa
}

\begin{abstract}
By analysing the industrial conflict that has affected the Indian Maruti Suzuki since 2011/2012, the article reflects on the meaning of the lean manufacturing paradigm today. It explores what continues to make it dominant, and the ultimate frontiers it has reached. It argues that its global significance could not have been established without the exploitation of local labour regimes, and without stretching their competitive advantage to the detriment of workers. In particular, the desirable condition now sought at global level is the possibility of relying on regimes based on high levels of casualisation, allowing the progressive "substitution" of permanent workers. However, as the Maruti case also reveals, working-class composition and the sustainability of the local labour process can generate mechanisms and unexpected alliances that could potentially destabilise the system. Indeed, the case shows how corporate strategies intended to fragment and depoliticise labour, inbuilt into the paradigm, were directly challenged and encountered resistance. Ultimately, though, the case also shows how, without strong legal and political support, the potential of a labour movement can be suffocated by institutionalised violence. In this sense, lean reacts, and the despotic imposition of consent becomes visible as never before.
\end{abstract}

\section{KEY WORDS}

Casualisation; India; Automotive; Lean Manufacturing; Maruti

\section{Introduction: A Milestone within Indian Industrial Relations}

In 2011/2012, an unprecedented wave of strikes shook the Delhi auto cluster in the Indian National Capital Region (NCR). Workers from one of the Indian auto "champions", Maruti Suzuki, engaged in one of the most prolonged and intense forms of collective action that India witnessed since liberalisation. In the industrial history of the region, the strike was unprecedented in all respects. It was unprecedented for its duration, the modalities of struggle, and the demands that were raised. It was unprecedented for the composition of the workers who took action, and for the unity and solidarity they managed to build, despite the imposed lines of fragmentation. It was unprecedented for the violent repression that followed, leading to the utter violation not only of labour and union rights, but also of basic human rights. It was unprecedented for its legal outcomes and the use of institutional coercion, which make it one of the worst onslaughts on labour India has seen in recent times.

Overall, the Maruti dispute undoubtedly set a milestone within Indian industrial relations, and within the industrial development trajectory the country has followed in the past few decades. It is therefore a story worth exploring. Indeed, inscribed into a broader study of management and production strategies, and of industrial relations in the global auto industry, such a case may prompt 
interesting insights on what lean manufacturing means today. For instance, it may contribute to an understanding of the practical implications of the model, and of the ultimate frontiers it has reached. Looking at labour, the story not only represents an extreme case in terms of reliance on casualisation as a competitive advantage, but also provides a unique example of solidarity bonds expressly built to challenge it. Eventually, despite its dramatic outcome, the case may still teach important lessons, both on capital strategies and on labour organising.

Drawing on empirical literature on lean manufacturing (Charron and Stewart, 2004; Stewart et al., 2004, 2009; Danford et al., 2008; Pulignano et al., 2008), seen as the expression of well-defined politics of production (Burawoy, 1985), and based on field research conducted in the NCR auto cluster in 2011/2012, ${ }^{1}$ this article builds on the Maruti case to discuss what such lessons could be.

\section{Lean in Practice and the Maruti Model}

A look at the distance between the narrative that still accompanies the lean production model and its practical implications may provide important interpretative keys for the analysis of contemporary processes of industrial restructuring. Firstly, it may lead to further questioning of the universal applicability and global significance of the original lean recipe (Womack, Jones and Roos, 1990) by highlighting the fundamental role played by local conditions and labour regimes in determining the success of the model. Secondly, it may help debunk myths associated with the lean discourse by disclosing the gap between its rhetorical claims and the "lived experiences" of industrial restructuring. Thirdly, the analysis of corporate strategies following the implementation of the model, and of forms of resistance to it, may contribute to identifying potentially sensitive areas affecting its outcomes and where its weaknesses could lie.

Twenty-five years ago, the lean production paradigm, as first designed within the Toyota factory, was presented as a revolutionary recipe that would re-shape the destiny not only of the global auto industry, but of the entire manufacturing system worldwide (Womack et al., 1990). In its ideal design, the term lean alludes to a light, agile system of production and management, where all unnecessary burdens are eliminated - excess stocks, prolonged times, superfluous spaces and unneeded human efforts - within a flexible structure that aims at optimising times and linkages between producer and consumer on the one side, and between managers and employees on the other. Overall, the system generally entailed changes in the production planning process in order to adapt to customer preferences, the reorganisation of spaces and times of manufacturing operations within and outside the factory, and workers' involvement through the establishment of new company values. In practice, the built-to-order system, or just-in-time achieved through the kanban method, ${ }^{2}$ often requires the spatial restructuring of production operations and the vertical disintegration of manufacturing activities. ${ }^{3}$

${ }^{1}$ The field research involved interviews with unions present in the area, business associations, a Maruti manager, focus groups with workers, and a questionnaire survey on "Working and Living Conditions in the NCR Auto Sector", comprising 140 valid responses from both original equipment manufacturers (OEMs) and suppliers.

2 Method to control the whole logistics of the chain in order to reduce the accumulation of stocks to the bare minimum by setting a strict limit to the work-in-progress inventory.

${ }^{3}$ This includes processes of clusterisation, outsourcing, and the progressive formation of production chains, all aimed at the flexibilisation of productive relations between assemblers and component suppliers. For recent research, also on India, see Tewari (2008), Knorringa (2005), Das (2005) and Landy and Chaudhuri (2004). 
Inside the factory, while restructuring often involves a reorganisation of assembly lines, a system to quickly detect production flaws is also devised, based on the idea of involving all workers in the attempt to ensure continuous improvements - known as kaizen - in the manufacturing process. The engagement of workers is also achieved via the creation of teams and the appeal to company values, reinforced through the provision of material incentives. ${ }^{4}$ Here, the objective is to let workers develop a sense of belonging, of ownership of the activities they undertake, and of responsibility towards their fellows.

Today, almost three decades after the formal introduction of the model, its real meaning, implications and impact can be analysed rather distinctly. While it has undoubtedly spread worldwide, to the extent of permeating the productive rationale of economic sectors well beyond manufacturing, ${ }^{5}$ the lean paradigm was rarely applied integrally, often encountered glitches, and reached very different outcomes depending on the context. There is no doubt that its implementation disclosed a substantial gap between the rhetorical announcements that accompanied its introduction, and the lived experiences of those who enable the lean factory to function - the workers. When lean was translated into practice, not only did the demand for labour flexibility enormously surpass the innovations implemented within the factory's productive process, but all forms of required flexibilisation had a negative and heavy impact on the workforce. In this sense, restructuring generally caused the intensification of the working pace and of the pressure put on workers. In addition, the internal disintegration of manufacturing activities and the subsequent outsourcing of productive segments to external firms were often accompanied by processes of informalisation and growing insecurity in employment relations. Finally, far from leading to a progressive empowerment of the labour force, the flexibility imposed on workers - a crucial node of the lean manufacturing system - rather contributed to its increasing precarisation and depoliticisation. In this sense, and as the Indian case will show, while political neutralisation appears to be an essential ingredient to secure consensus (CRS, 2011), it does not always succeed.

Concerning concrete manifestations of the lean model, there is a rich literature reporting how its "lived experiences" mostly resulted in a further burden imposed on workers. For example, Moody (1997) clearly illustrates how the employers' demand for functional, numerical and time flexibility, to which the workforce is expected to conform, often translated into the free allocation of workers according to temporary industrial needs, and arbitrary adjustments to the number of workers employed and the length of operations they performed. Such adjustments are either managed internally, through the pursuit of specific corporate strategies like sub-contracting part of the workforce to external companies or recruitment agencies, and the increasing employment of casual/temporary workers, who are easy to dismiss. Or, otherwise, pressure is put externally by lobbying political institutions for the flexibilisation of labour market regulations: easier hiring and firing procedures, fewer limitations on the use of contract labour, and simplification of bargaining mechanisms.

Overall, the application of the core "tenets" of the lean paradigm revealed a reality fairly distant from the promised ideal type. For example, Cardoso (2004) spells out how the restructuring of workplace relations at the Betim FIAT plant in Brazil, the consequent allocation of workers to

\footnotetext{
${ }^{4}$ Like seniority bonuses or productivity prizes, or the promise of long-term employment, sometimes even lasting for life (Womack et al., 1990).

${ }^{5}$ See, for example, the studies conducted by Carter et al. $(2011,2013)$ on the UK civil service.
} 
elementary working units (EWUs), and the distribution of both material and symbolic benefits, which was meant to secure loyalty to the benevolent Familia FLAT, hid a well-designed model of factory control. This also manifested in the selection of a greenfield site with no history of labour organisation and through repeated, firm anti-union behaviour. Examining cases of restructuring at FIAT, Renault and Volkswagen, Pulignano and Stewart (2008) note how the implementation of teamwork was expressly employed as a tool to discipline workers, whereas the systematic use of punitive measures and reward mechanisms in the form of welfare benefits and incentives acted as a structure for labour regulations aimed at controlling labour. Stewart et al. (2009) further underline how, even where worker involvement and worker autonomy were somewhat promoted, their meaning was nevertheless defined by management itself. No spontaneous and self-determined organisation was contemplated, while union representation and independent actions were radically obstructed within a broader design of labour de-politicisation and conflict prevention.

In the same way, the idea of continuous improvements seems to represent the pursuit of continuous cost reduction rather than actually providing any substantive betterment of either product quality or working conditions (Moody, 1997; Pries, 2004). Productive improvements were often achieved through the partial reorganisation of assembly lines. Thus, spaces between workers and workstations were reduced, tasks were standardised, and work pace was made uniform. This translated into increasing pressure on the line, intensifying rhythms and heightening stress. Investigating the impact of lean manufacturing on labour within the British auto-component segment, Danford (2004) notes how the combination of team-working and the kaizen methodology intensifies disciplinary pressure and more pervasively subordinates the worker to supervisors and the machine.

An acceleration of working rhythms and the spatial reorganisation of assembly lines were also a direct outcome of the implemented just-in-time. In practice, this influenced both the spatial configuration of production sites, and the organisation of the labour process. Inside the large factory, the pursuit of "leaner" structures led to both the optimisation of times and spaces on the assembly line, and to the vertical disintegration of manufacturing operations. This also meant the externalisation of the production of most components through outsourcing and sub-contracting to smaller suppliers located outside the large assembly plant. Such processes not only involved a reshaping of geographical settings, but also affected the workforce. For example, outsourcing meant not only cutting production costs, but also reducing labour costs. It meant shoving workers to firms generally dispensing lower salaries, forcing them into more precarious employment relations, and into more "flexible" labour regulations that often provided less protection. In countries like India, this has involved the contractualisation, informalisation and casualisation of the labour force in particularly harsh ways, and a progressive move from more protected and regulated to less protected and less regulated segments. On the global level, outsourcing was a key part of the exportation of the Toyota lean system abroad, within a trend that has seen labour being progressively pushed down the production chain, confined to lower wages, less job security and poorer working conditions (Moody, 1997).

In the Maruti case, the introduction of the lean model was channelled by the first partnership with the Japanese company Suzuki in the early 1980s. What was greeted as the "Maruti revolution" (Ishigami, 2004) undoubtedly entailed an injection of capital, new technology and innovative management techniques into the Indian industry (D'Costa, 1995). Symbolically, the newly born Maruti Suzuki chose the industrial area in Gurgaon-Manesar (NCR) as an ideal greenfield site on which to build new plants, train a new workforce according to the new company values, and implement a new managerial mission. In the factory, the organisation of production in the name of flexibility entailed a 
redistribution of tasks between assemblers and suppliers (through frequent outsourcing), increasing automation, a reduction in the number of workstations, and a faster, never-stopping assembly line (Jha and Chakraborty, 2012, 2014). In practice, as workers from the Maruti Manesar plant testified during the survey conducted in 2012, this resulted in an extremely fast speed on the line, continuous and repetitive operations, and control and harassment on behalf of contractors and supervisors meant to secure flawless operations (author's own field survey, 2012). In addition, direct accounts collected through focus groups report breaks of only seven minutes, compulsory overtime of up to two hours per day, punishments and salary deductions for every minute of delay, forbidden communication among workers and frequent harassment on the line. ${ }^{6}$ Maruti's flexible production was thus achieved through very intense working rhythms, strictly controlled operations and an extremely disciplined workplace. The necessary discipline was also maintained through strategies aimed at keeping the workforce fragmented and depoliticised, and the factory as free as possible from political interference. As we will see in the next sections, these involved the initial selection of a greenfield site without a rooted union tradition, repeated attempts to prevent the formation of new unions, the extensive employment of a casual workforce and, particularly in the end, the use of police repression and institutional violence as coercive tools. However, such strategies did not always succeed: before eventually regaining terrain, they encountered significant resistance and were properly challenged.

\section{NCR Auto Workers and the Contract Labour Issue: An Explosive Potential?}

Besides the working conditions experienced in the Maruti factory, the composition of workers in the NCR auto cluster may also explain why the situation became unsustainable and why the apparent industrial peace ${ }^{7}$ on which Maruti had built its lean model eventually collapsed. Here, the overall picture is derived from a questionnaire survey on "Working and Living Conditions in the NCR Auto Sector" carried out in the spring of 2012. This covered six original equipment manufacturers (OEMs) and thirteen component suppliers, ${ }^{8}$ for a total of 140 valid responses. ${ }^{9}$

In order to understand the profile of the surveyed workforce it is important to first consider the context in which the 2011/2012 Maruti strikes broke out. As mentioned earlier, within the NCR, the Gurgaon-Manesar area was originally chosen as a greenfield site in which to establish new plants (one opened in 2000, one in 2006) and to build an industrial township around Maruti. Initially, the cluster

\footnotetext{
${ }^{6}$ Interviews were personally conducted with representatives from all the national unions active in the GurgaonFaridabad area, and focus groups with workers from both the Gurgaon and Manesar Maruti plants were held in the months between March and August 2012. For further reports, see also GWN (Undated), FMS (2011), PUDR (2013) and ICLR (2013). Reporting on factory conditions in excellent detail, the People's Union for Democratic Rights (PUDR, 2013) describes a "dehumanisation" of the workforce, which is compelled to meet the target of one car every 42 seconds, even if this means insufficient time to rest within and between shifts, physically draining rhythms, no paid overtime and no leave.

7 Interview with Maruti manager, Delhi, 6 September 2012.

${ }^{8}$ Questionnaires were collected anonymously, and firms were anonymised during data processing.

9 The questionnaire was composed of four main sections: A) personal details (gender, age, education, origin); B) working conditions (workstation, shift, facilities, safety, contract, salary); C) living conditions (family, commuting, living expenses, social benefits); D) labour rights/organisation (union membership, personal opinions on general strike, etc.).
} 
attracted investment and foreign companies not only for its good infrastructure provision, its proximity to the Delhi retail market and decision-making centres, and the available pool of skilled workers (Narayanan and Vashist, 2008), but also for its advantages as a newly industrialised area. This included the possibility for OEMs launching new assembly plants to hire a young workforce - in their first employment and with no memory or experience of previous struggles, and in an area that did not yet have a particularly rooted union tradition (author's own field interviews, 2012).

Indeed, our survey confirms the presence of a young, educated workforce, with relatively short employment relations. Workers' age gaps, education levels and duration of employment can be observed in Figures 1, 2 and 3. As we shall see when discussing the strike demands and dynamics in the next section, the workers' young age, good education levels and lack of political experience, while part of the advantage sought by the employing companies, also played a role in pushing the workers to take action. Indeed, they affected the workers' expectations in terms of living standards, which clashed with their actual working conditions, and probably the way they dealt with the escalation of the industrial conflict. Other interesting findings that can help interpret what happened at Maruti concern the supposed fragmentation of the workforce as per the origin and status of the workers, and their average remuneration.

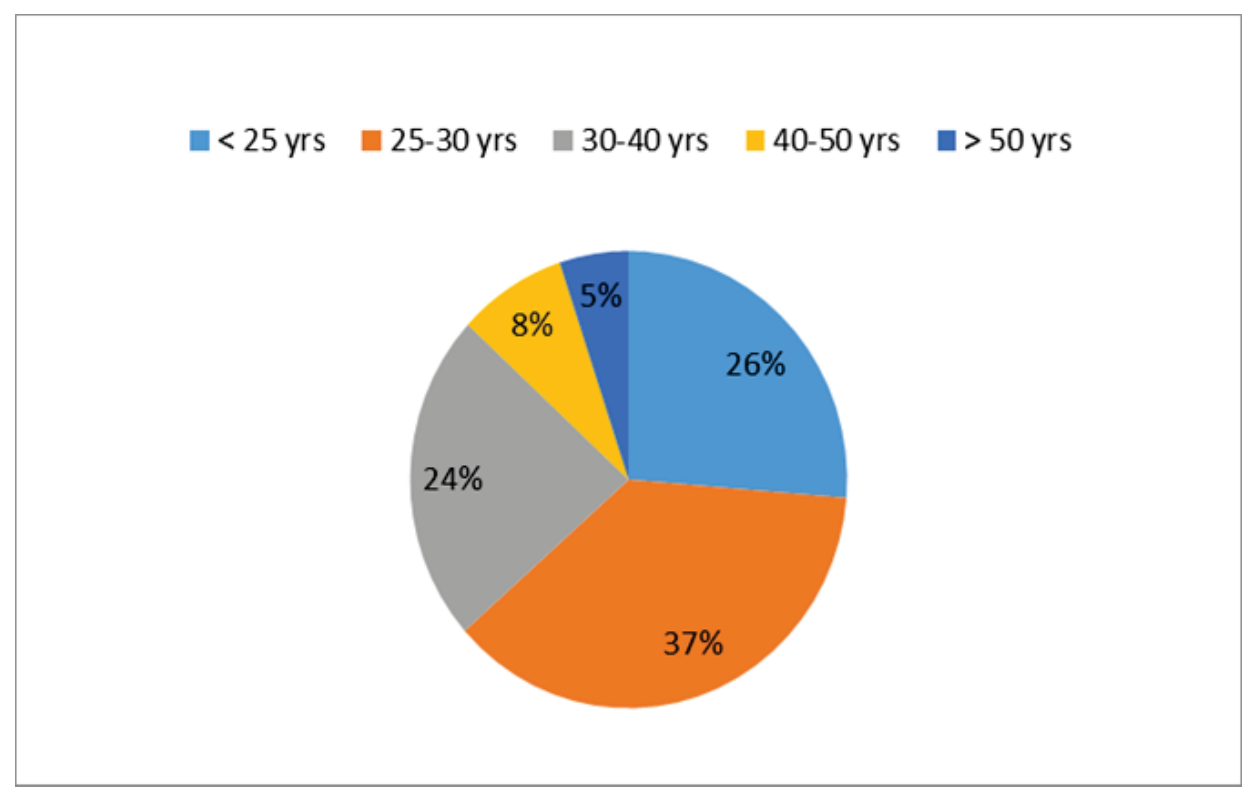

Source: Author's own field survey, March/April 2012.

Figure 1: Composition of workers by overall age group 


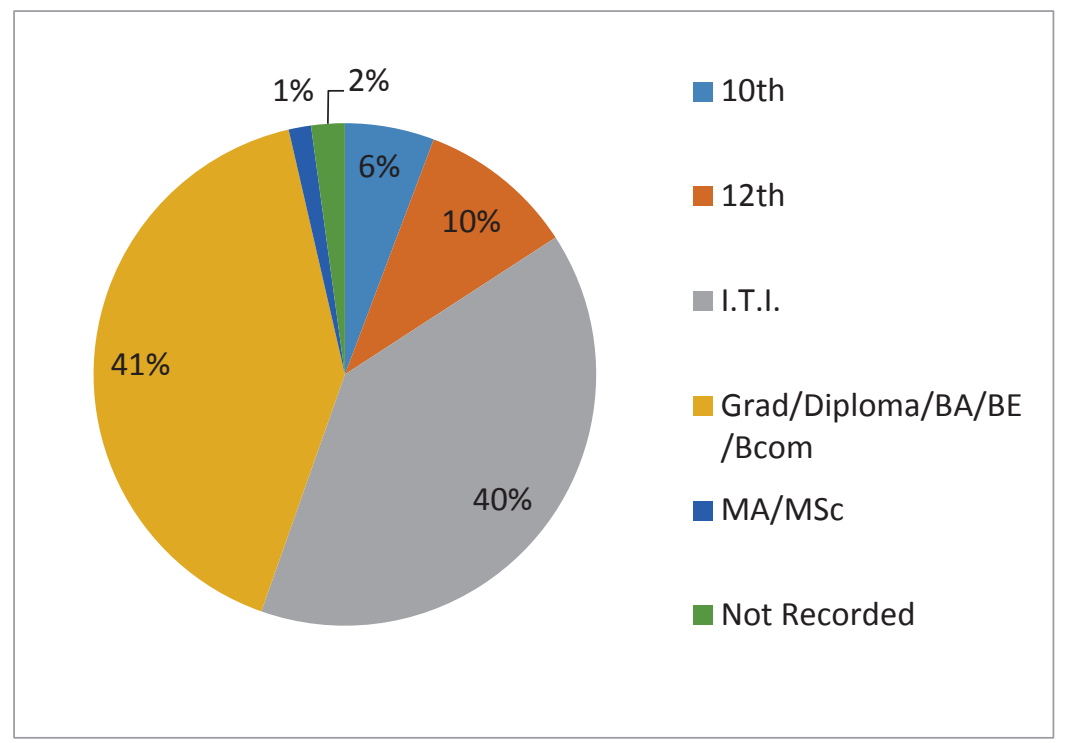

Notes: $10^{\text {th }}$ and $12^{\text {th }}=$ Grades 10 and 12; I.T.I. $=$ Industrial Education Institute. Source: Author's own field survey, March/April 2012

Figure 2: Composition of workers by education level

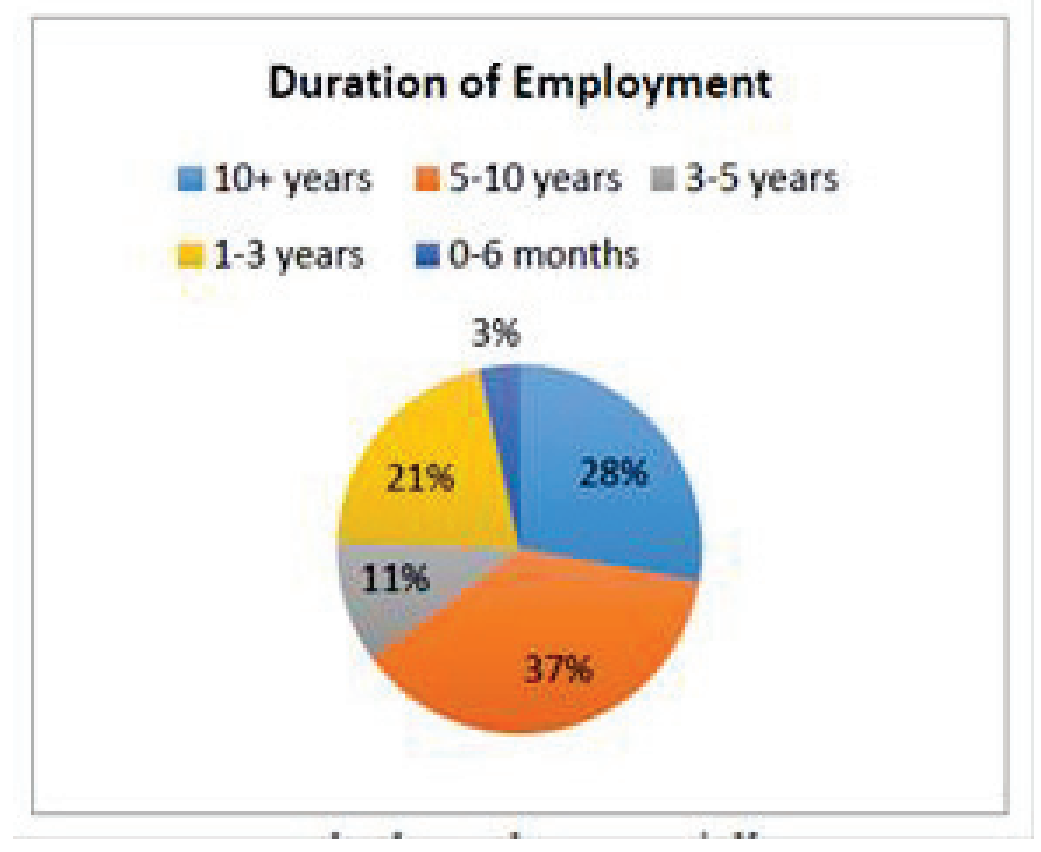

Source: Author's own field survey, March/ April 2012.

Figure 3: Composition of workers by duration of employment 
As far as the workers' states of origin are concerned, our sample came from fifteen different states (see Figure 4).

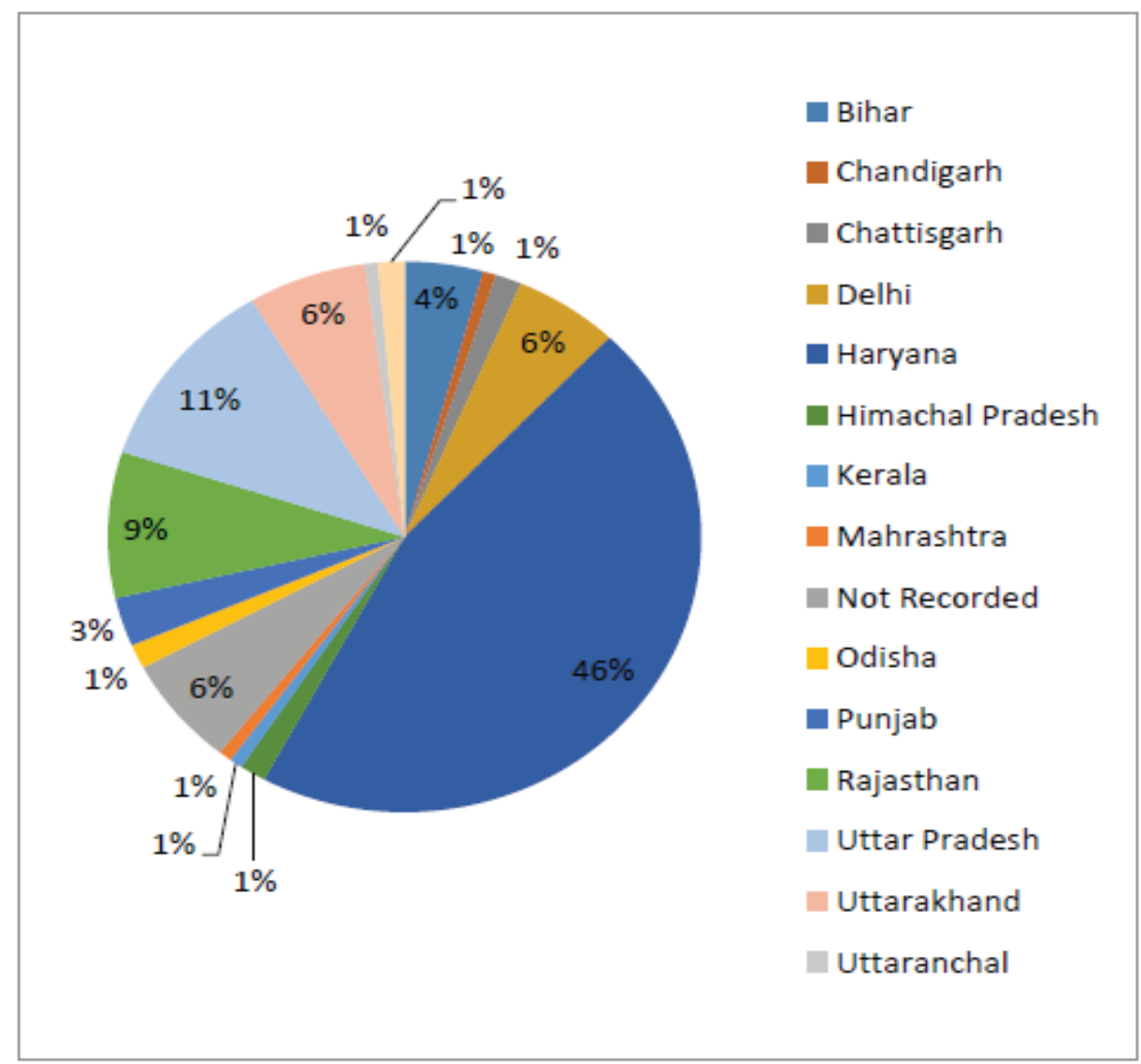

Source: Author's own field survey, March/April 2012.

Figure 4: Composition of workers by state of origin

It must be noted that, although almost half of the workforce were from the state of Haryana, 48 per cent of workers came from different parts of the subcontinent, indicating a substantial proportion of migrant labour. If different origins of labour may play a limited role in fragmenting the workforce coming from the "Hindi Belt", this could also play a more significant divisive role for workers from Southern or Eastern states. In terms of employment strategies, the use of migrant labour was expected to act as a deterrent to workers' organising and engagement in struggles, due to different cultural and linguistic backgrounds and the frequent need to financially support families back home. ${ }^{10}$

Another major line of segmentation related to the employment status of the workforce (Figure

${ }^{10}$ Interviews with CITU, AITUC, NTUI, Delhi, 2012. 
5). Despite limitations in approaching respondents, ${ }^{11}$ it is clear from the sample that almost a third of workers held non-permanent positions (13 per cent casual, temporary or contract workers, and 12 per cent apprentices/trainees).

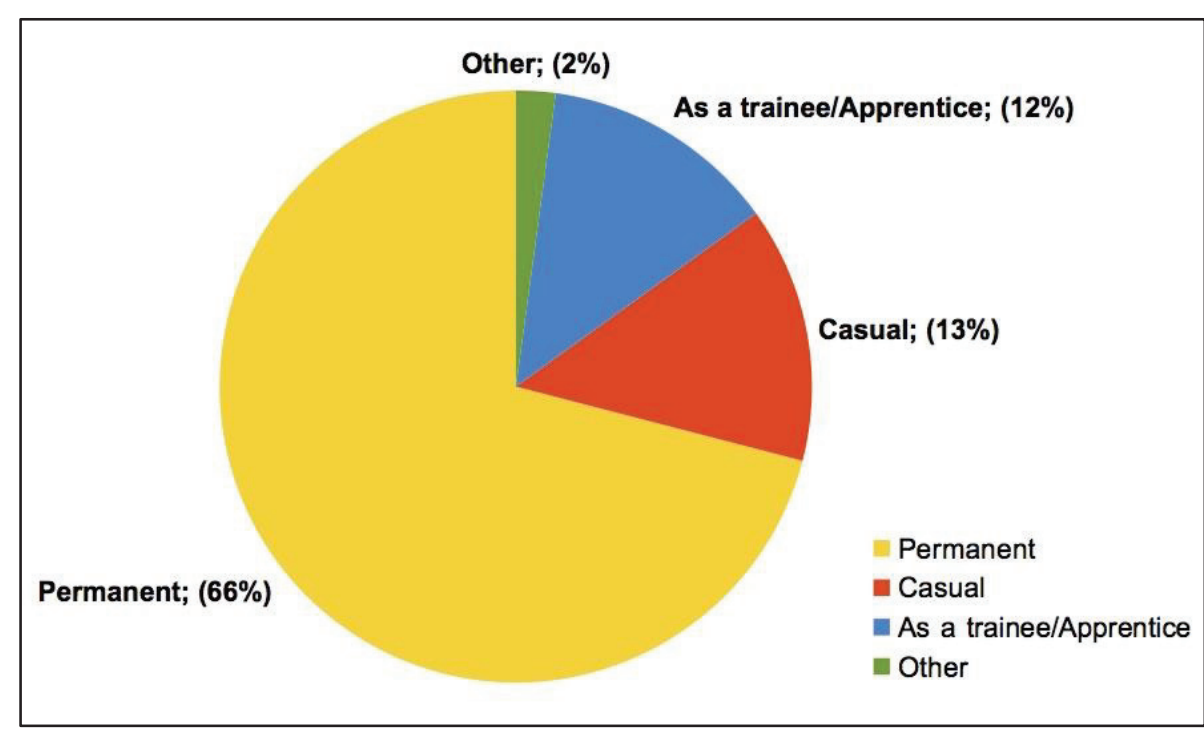

Source: Author's own field survey, March/April 2012.

Figure 5: Composition of workers by status of employment

The existence of workers of different employment statuses, experiencing not only very different wage levels but also different degrees of social protection and often differential access to political representation, must be ascribed to a widespread process of casualisation in the area and to the specific issue of contract labour. The latter has emerged powerfully in the last few years, finally appearing on the agenda of national general strikes organised by major union federations, and even prompting casual workers to bravely fight on the forefront - as the story told in the next section will show. The nature of the problem surfaces distinctly if we consider the extent of the contractualisation process within Indian manufacturing (see Figure 6), the use (and abuse) of contract labour in relation to the existing law, and the working conditions endured by contract workers.

\footnotetext{
${ }^{11}$ The majority of workers approached to complete the questionnaires, and those who helped to distribute them, were selected through unions that acted as facilitators. This might have caused a bias in the direction of more permanent and unionised workers, who would be less concerned than casual workers in terms of political exposure in a period of unrest and tension.
} 


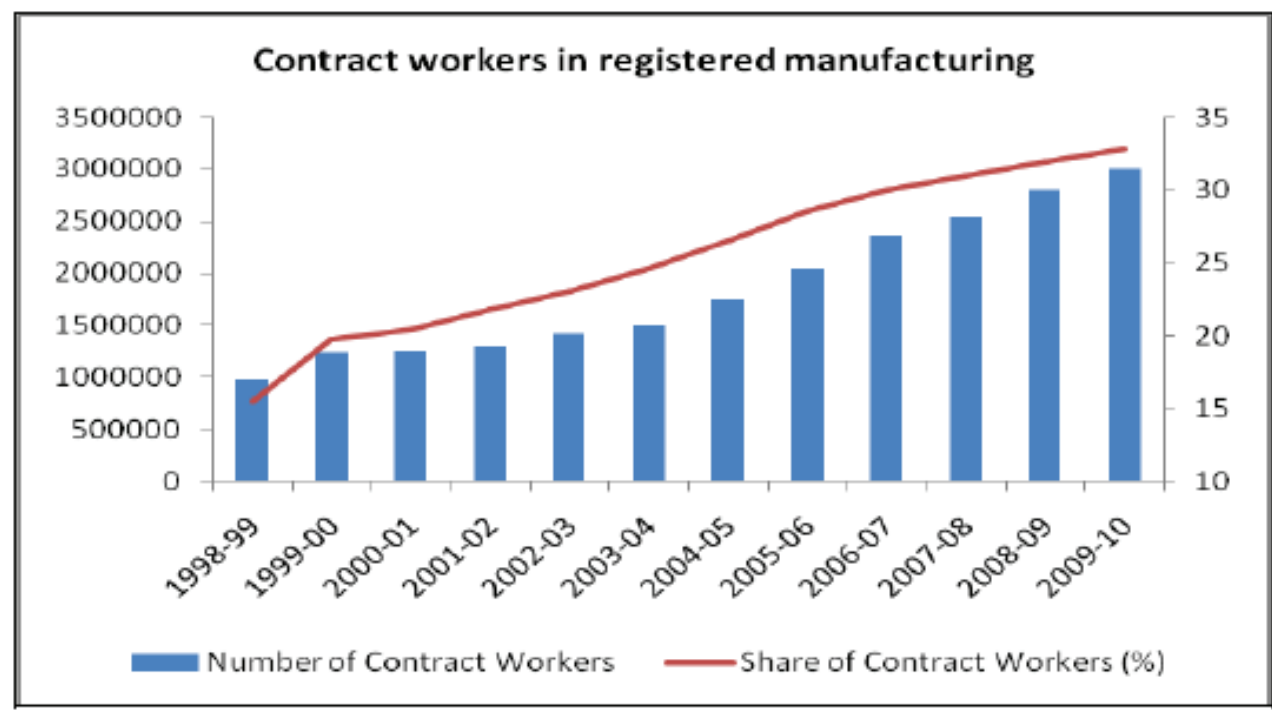

Source: Chandrasekhar and Ghosh (2014:2.)

Figure 6: Contract workers in Indian organised manufacturing

The increasing share of informal, "more flexible" labour within Indian organised manufacturing has been documented widely by extensive studies. Deshpande et al. (2004), for example, report how the use of non-permanent workers has particularly intensified within large firms employing 500 or more workers. Convincingly overcoming the conceptualisation of a dualism between organised and unorganised segments, the authors illustrate how a process of casualisation has progressively permeated the formal sector through an overt substitution of permanent workers with temporary, casual, contract labour. In the NCR case, this process not only helps the employer increase profits by lowering costs, but is generally pursued to "manage industrial relations in an orderly manner" (Deshpande et al., 2004: 85). This trend is confirmed by Barnes, Lal Das and Pratap (2015), who show how the widespread adoption of a contract labour system in the NCR not only allows firms to reduce costs, but ultimately works as a strategy of labour control in which collective bargaining and trade union rights are frequently denied. Indeed, as it also emerges through our survey findings, we see the rooted practice of remunerating casual workers with wages much lower than those paid to their permanent counterparts (see Table 1). Employers are seeking to maximise the use of casual workers as they are easier to dismiss and, according to the existing law, generally not entitled to union membership.

Table 1: Minimum and maximum salary per group of companies (in INR per month)

\begin{tabular}{|l|l|l|}
\hline Group & Min salary & Max salary \\
\hline OEMs & 4000 & 60000 \\
\hline Vendors & 7000 & 28000 \\
\hline
\end{tabular}

Source: Author's own field survey, March/April 2012. 
Considering the NCR, a process of "casualisation by substitution" has clearly taken place following all the major labour struggles. For example, after the 2000 Maruti Gurgaon strikes, the company terminated more than 2000 employees, replacing them with contract workers. ${ }^{12}$ Within an overall process of informalisation of the organised manufacturing segments, the rising employment of contract workers has been particularly prominent. Together with non-permanent workers, contract workers can be classified as a specific category of casual/non- regular employment (Deshpande et al., 2004). As with all casual workers, contract workers tend to receive lower wages and more restricted social benefits, and generally cannot subscribe to union organisations, keeping them excluded from political representation. In addition, they are distinguished by their "indirect" nature: they are hired by a third party and are not directly connected to the main company in terms of employment relationship and methods of wage payment. Normally, they should be hired, supervised and remunerated by a contractor, who in turn is generally compensated by the "mother company" (AIOE, 2013).

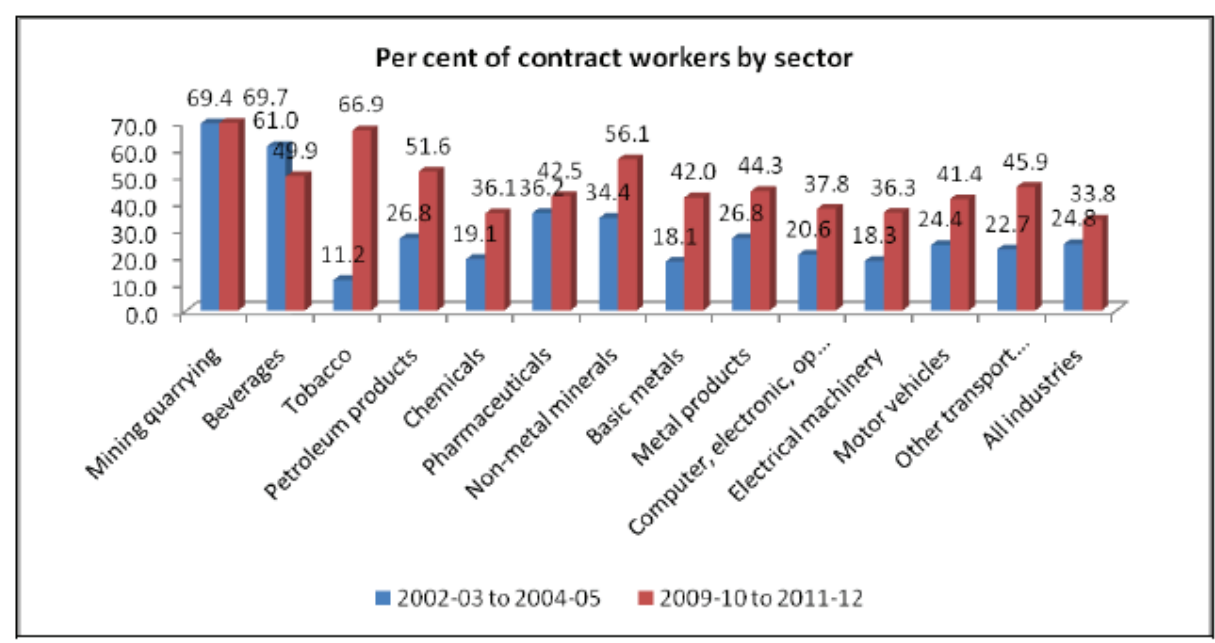

Source: Chandrasekhar and Ghosh (2014:3)

Figure 7: Percentage of contract workers by productive sector

The reason why the contract labour system has recently become a matter of contention and generated widespread protest has to do with its over-use and abuse, in overt violation of the existing Contract Labour (Regulation \& Abolition) Act $1970 .{ }^{13}$ Firstly, the increasing and extensive employment of contract workers has occurred despite the legal limitations forbidding its use within "core activities" and on works of "perennial nature" (Papola, 2013). In addition, the system has channelled the creation

12 From an interview with the leader of the 2000 Maruti strike, Delhi, 26 August 2012.

${ }^{13}$ In recent years, amendments have been proposed to overcome the "rigidities" of the act, but the original act is still in force. For example, in March 2016, the Haryana State passed four amendments to allow easier lay-offs by enterprises with more than 300 employees, and to increase the number of contract workers permitted. See http://indianexpress.com/article/cities/chandigarh/haryana-pushes-for-change-in-labour-laws-passes-4-bills. 
of a separate category of workers, employed at cheaper rates and excluded from social security schemes, despite the Contract Labour Act's requirement to provide contract workers with regular salaries and at least minimum social benefits (Papola, 2013). Thus, in spite of supposed restrictions, the use of contract labour within organised manufacturing has grown considerably, increasing from about 20 per cent in 2000/2001 to 33 per cent in 2009/2010 (Chandrasekhar and Ghosh, 2014; Papola, 2013: 22; see also Figure 7). Within the whole auto industry, more than a third of the workers currently seem to be employed on a contract basis. ${ }^{14}$ At company level, especially within large firms, the share of contract workers has sometimes - illegally - outnumbered that of permanent workers. Concerning the NCR auto factories, union representatives report 60 per cent of contract workers at Honda and over 90 per cent at Hero Honda Haridwar (author's own field interviews, NCR, 2012), while PUDR (2013) states that, by the time of the 2012 strikes, Maruti employed at least 40 per cent contract workers, and over 60 per cent at the Manesar plant. Today, Maruti seem to have adopted yet another shade of casualisation: following the extensive protests in 2012, thousands of contract workers were turned into "company casuals", hired directly by the company and no longer through a contractor, but still on casual terms (GWN, Undated; Youth Kiawaaz, 2017). Publicised as a move to limit the employment of contract workers and their continuous in-sourcing, this strategy actually seems to be a way to maintain the advantages of casual labour while exercising more direct control over it.

Beyond the high number of non-regular employees, the system itself rests on diffused irregularities and violations. These include protracted rolling-over of contracts in cases where workers should be made permanent, salaries below the statutory minimum wage and lower than permanent counterparts despite the performance of identical tasks, as well as a lack of written agreements, absence of paid leave and denial of social security schemes. ${ }^{15}$

In addition to the harsh working conditions, the insecurity related to the frequent employment on casual terms and, as we shall see, the continuous opposition to workers organising, another important factor to consider is the level of remuneration in an area with increasing living costs. The survey findings on wage levels for 2012 are reported in Table 1. As can be observed in the figures shown in the table, there is a huge disparity between minimum and maximum salaries, with a much wider gap in OEMs compared to vendors. Within the gaps themselves, salaries range from about onefourth of the minimum wage set by the State of Haryana (15 000 INR) to four times the minimum wage. This is explained by the presence, at the lower end, of poorly paid "helpers" (production assistants used as support on the line), while at the upper end a few engineers or older workers who have matured seniority benefits (in the plants of older formation) shift the maximum upwards. In addition, it is interesting to report the recorded salary gap between permanent and casual workers, which was 21281 vs 6083 INR in 2012 (author's own survey, 2012). ${ }^{16}$ Finally, recorded salary levels can be compared with declared average living expenses (Table 2). Although the amounts represent averages, they are sufficiently explanatory to conclude that the salary levels of casual/contract workers are very inadequate. Of course, averages do not express the real gaps and the actual disparities in living standards that characterise the Gurgaon region. While old Gurgaon, where most workers live, is still a

\footnotetext{
${ }^{14}$ Interview, Prof. Dev Nathan, ISLE Delhi, November 2011.

${ }^{15}$ For example, they are often denied bonuses, insurance, medical assistance and pension schemes related to Provident Funds and the Employees' State Insurance Scheme.
}

${ }^{16}$ Later raised, following the massive protests. 
village with poor housing, bad roads and poor facilities, the newly built part of Gurgaon is connected to "shining India" through the brand-new Delhi metro. Malls and office buildings mushroom all around, and living costs skyrocket accordingly. ${ }^{17}$

Table 2: Average monthly expenses (in INR)

\begin{tabular}{|l|l|}
\hline Expenses & Monthly average \\
\hline Housing & 7211.34 \\
\hline Food & 5266.67 \\
\hline Medical care & 1310.00 \\
\hline Transportation & 1590.21 \\
\hline Education & 3647.37 \\
\hline Extra & 3049.21 \\
\hline Total & 22074.80 \\
\hline Source: Author's own field survey, March/April 2012
\end{tabular}

\section{Maruti's Unrest: Beyond Divisions and Traditional Representation}

After a series of relatively milder strikes that affected the NCR in the 2000s, the unrest that broke out at the Maruti Manesar plant in 2011/2012 exploded as a powerful warning signal, drawing wide attention not only to the Maruti lean model, but more broadly to the "Indian way" of factory management and industrial development. Within the discussion developed so far, it represents a particularly meaningful case, considering that the whole Gurgaon auto cluster developed around the myth of the "Maruti revolution" (Ishigami, 2004), and that Maruti still proudly claims to found its management and production strategies on the principles of Total Quality Management, to use the kaizen methodology with the idea of achieving continuous improvements by involving all workers, and to focus on teamwork and a just-in-time structure. ${ }^{18}$ However, despite the favourable conditions and the optimal location, the NCR "industrial peace" soon collapsed. Starting from the oldest Maruti Udyog Limited (MUL) plant in Gurgaon (2000), followed by Honda (2005) and RICO (2009), and culminating in the intense Maruti Manesar strikes in 2011/2012, a whole series of labour struggles highlighted the inconsistencies, contradictions and weaknesses of the Maruti-style industrial model. ${ }^{19}$

Overall, this series of strikes denounced a regime based on strict labour control, on fierce antiunion behaviour and on state-management connivance in the modalities of repression. Such issues

\footnotetext{
${ }^{17}$ Lower-paid, mostly casual workers generally live in rooms shared with two, three or four other workers in one of the villages close to the factory plants, where rents are cheaper but houses are overcrowded and water/electricity provision can be poor. I personally visited workers living in the Aliyar workers' village in Manesar, in April 2012, together with some activists from the Gurgaon Workers News .

${ }^{18}$ From an interview with a Maruti Suzuki India Ltd manager, Delhi, 6 September 2012. For an interesting reading on the "Maruti formula - lean manufacturing", see FMS (2011).

${ }^{19}$ From an interview with a representative of NTUI Haryana, 22 March 2012.
} 
also emerged throughout the 2011/2012 Maruti strike, which even more powerfully laid bare the actual implications of the factory regime built in the area, and was also exceptional for its duration, its intensity and its conclusions. On the whole, in the period from June 2011 to July 2012, the Manesar protest involved two main factory occupations, tool-down strikes, a 33-day company lock-out, dismissals and suspensions, and militarisation of the area through a fence erected outside the factory premises (GWN, Undated; PUDR, 2013). Eventually, after more than thirteen months of arm-wrestling, open and "underground" negotiations, threats and imposed conditions, ${ }^{20}$ the strike ended with an "accident". On 18 July 2012, an altercation between a worker and a supervisor ended with the worker's suspension, which generated widespread tension and a collective reaction. Violence broke out in the Manesar plant, also involving a fire in which an HR manager died and several workers were injured (PUDR, 2013). This resulted in blanket arrests and fierce repression: within a month, the employment of 546 permanent and 1800 contract workers was terminated and almost 150 workers were jailed, including all union leaders. ${ }^{21}$ Although it was proven that the arrests were executed randomly and there never was a fair trial or official conviction, and despite media involvement and pressure from outside, 148 workers were kept in jail until March 2015, ${ }^{22}$ with violence, torture and abuses reported throughout their detention (ICLR, 2013). Only very recently, on 10 March 2017, a final sentence was pronounced: thirteen workers were charged with murder and eighteen with rioting, and the rest were acquitted. Among those accused of murder, who can thus be condemned to the highest sentence, were the main leaders and office bearers of the union (Hindustan Times, 2017; Times of India, 2017; Youth Kiawaaz, 2017).

Besides the intensity and modalities of the struggles, what was extremely peculiar in the Maruti case was the composition of the workers who engaged in the strike and the demands they forwarded. Eventually, the legal outcome of the process makes the dispute particularly powerful in unveiling corporate strategies of labour control, where the system shakes, and how it reacts violently.

Concerning the profile of the workers who took action, it corresponds to the main findings of our survey on workforce composition: they were impressively young, educated and, most strikingly, largely employed on casual terms. The plant where the strike broke out is in fact the Maruti Suzuki, a plant in IMT Manesar, inaugurated in 2006. When it opened, the company recruited the majority of workers directly from industrial education institutes and technical colleges, thus securing a pool of young, skilled and "committed" workers - a generation of workers who have become the symbol of the modernising "shining India", striving for growth, progress and personal achievement; a generation of workers who were supposed to be easy to control, as they were not yet politicised, within an area relatively free from established unions; a generation of workers, however, who soon experienced the alienation of backbreaking work on the line, and saw rosy aspirations clashing with the reality of rampant casualisation and the brutality of an oppressive management (The Indian Express, 2011). In this sense, the tough working conditions and the relentless rhythms imposed by the Maruti lean factory seem to have proven particularly unbearable.

${ }^{20}$ Like the signature of a good conduct undertaking (GCU) as a condition to be re-allowed into the factory premises after the strikes (from an interview with one of the leaders of the 2000 Maruti strike, held in Delhi on 26 August 2012).

${ }^{21}$ From an interview with the leader of the 2000 Maruti strike, Delhi, 26 August 2012.

${ }^{22}$ News from March 2015 reports that 81 workers were finally granted bail of 25000 INRs, while more than 60 were still in detention at the Bhondsi jail in Gurgaon. Read (Business Standard, 2015; IndustriALL, 2015). 
The large proportion of casual workers involved in the Maruti strike was indeed a very surprising, peculiar feature. Despite the higher vulnerability of their positions and the precariousness of their employment relations, these workers did not hesitate to take action, and actually appeared on the frontline. Overall, the expected fragmentation between workers of different statuses did not prevent permanent and casual workers from striking together, within an incredibly inspiring manifestation of unity and solidarity, hardly observed before. ${ }^{23}$ In this sense, if the lower salaries and greater exposure to dismissals and terminations could have acted as deterrents, discouraging precarious workers from personal involvement in a strike, the Maruti events proved all expectations wrong. Likewise, if the employment of workers under different conditions and the concession of separate treatments might have created expectations of different needs and aspirations, rivalries and different willingness to fight, Maruti's ground reality also proved significantly different. Eventually, the perception of a common identity developed in a context of generalised exploitation and widespread oppression seems to have overcome all other forms of workforce segmentation that might have encumbered labour organising.

The composition of the striking workers also helps explain the demands raised in the Maruti protest. These revolved around two main claims: the recognition of an independent union, and the regularisation of contract workers. The request to form a union is connected to several issues. First, the autonomous initiative to form an independent union, in early 2011, and the long struggle until this was finally registered, on 1 March 2012, shows that the young, inexperienced Maruti workers gained collective awareness of their own conditions and developed a common political subjectivity. This entailed the acknowledgement of diffused exploitation, unjust employment relations and uneven power balances, up to the determination to act together in order to affirm collective rights. Although still at an early stage, this may be seen as the development of a common class consciousness where it was previously absent. Second, the need to establish a union seems both a response to the perceived lack of political representation, as well as an ultimate solution to address unbearable working conditions. Indeed, denunciations regarding the dehumanising conditions experienced on the line emerged vociferously throughout the entire strike, and the formation of a union came forth in the hope that what had long been silenced would finally come to the surface (PUDR, 2013). Third, it is important to note that the demand for an independent union did not happen in a vacuum, but came as a reaction to the long-lasting imposition of a "company union", a pre-existing management-friendly union whose leaders were selected by the company itself, with no involvement of the workers. In this sense, the request to recognise the Maruti Suzuki Employees' Union (MSEU), as opposed to the previous Maruti Udyog Kamgar Union (MUKU), discloses a situation of diffused political control and lack of democratic consultation, in which not only were union leaders directly chosen by the management, but no election was ever held. Finally, the initial absence of a workers' union, the protracted attempts to invalidate its registration, plus the subsequent retaliation targeting those recognised as its leaders, can all be included in a generalised hostility towards labour organisations and particularly accentuated within multinational companies championing the Japanese model of "collaborative industrial relations". ${ }^{24}$

With regard to the second core demand expressed by the Maruti strike, namely the regularisation

\footnotetext{
${ }^{23}$ Emerged from interviews held with all Gurgaon unions.

${ }^{24} \mathrm{~A}$ trend that was already clearly expressed in the Honda case a few years earlier. The longstanding hostility of Japanese management was clearly reported during discussions held with all unions active in the Gurgaon area.
} 
of contract workers, this must be analysed within the system we described in the previous section. The widespread employment of contract workers - and, following recent strikes, of "company casuals" in the NCR now seems to be the norm rather than the exception. The regular replacement of permanent workers in the aftermath of each protest, the massive retrenchments, and the shift back to "in-house" casuals, testify to the use of casualisation as an expressly political tool, which goes well beyond economic justifications. In this sense, Maruti's casual workers demonstrated not only a clear awareness of their conditions and a willingness to fight for better ones, but also an unwillingness to buy into management's divisive strategies by building bonds of solidarity with their permanent colleagues and struggling together.

Overall, what the Maruti protest powerfully disclosed was not only the actual scope of the "Maruti lean model", but also its limitations and potential weaknesses. Indeed, it not only laid bare the intensification of working rhythms, the unbearable conditions on the line, and the miserable remuneration of a segment of the workforce supposed to be "protected" and almost privileged compared to other industrial sectors. It also revealed the fallacy of the lean idea of consensus as nothing but an imposed, deceitful industrial peace built on labour control, forced de-politicisation and division. In this sense, the case unveiled, on the one hand, the strategic selection of a well-defined workforce and an (initially) politically neutral location; on the other hand, it showed clear efforts to obstruct unionisation and to lower costs while controlling labour through extensive casualisation. Eventually, the bar was raised even higher. The latest convictions, added to years of arbitrary detentions, the clear targeting of union officials and the threatening messages sent to all the workers in the area "not to do like Maruti" reveal the use of coercion and intimidation, an institutionalisation of violence beyond limits. Indeed, the shift to what Burawoy defines as hegemonic despotism is now evident (Burawoy, 1985; Stewart et al., 2004; Pulignano and Stewart, 2008). Consensus is not even formally demanded, and the use of coercive methods appears distinctly.

However, the case also shows how corporate strategies can encounter obstacles. Overall, the evident gap between the lean rhetoric and the local working and living conditions, the indiscriminate use (and abuse) of the contract labour system, the mismatch between actual possibilities of social reproduction and the aspiration of the young, educated working class, and the repeated attempts to prevent labour organising, rather than building a competitive advantage, resulted in an unprecedented wave of antagonism and indicated where the system can potentially be shaken. In this sense, despite lean's powerful rhetoric aimed at controlling labour, insubordination remains persistent and unresolved.

\section{What Lessons can be Learned?}

Within a study of production and management strategies implemented in the global auto industry and expressed by some of the most recent applications of the Japanese lean manufacturing paradigm, the case of the Indian Maruti Suzuki was chosen as being significantly revealing. In particular, an analysis of the strikes that affected the company in 2011/2012 was deemed meaningful for several reasons. Firstly, an analysis of the Maruti case contributes to highlighting the discrepancy between lean as hegemonic narrative and its lived experiences, as well as its real implications for those who allow the model to actually function - the workers. Once again, lean emerged as a rhetorical apparatus disclosing a profoundly ideological scope, visible in the managerial attempts to control, fragment and depoliticise labour. Secondly, the story of the Maruti unrest was chosen as epitomising the ultimate frontier of 
labour exploitation and control, namely the reliance on labour regimes based on high levels of casualisation.

On the one hand, this responds to the relentless need of companies to lower costs in order to secure higher returns to capital, which are particularly acute in times of crisis. On the other, it provides a brilliant opportunity to further fragment and depoliticise labour through structural impediments to labour organising. However, while globally pursued as a competitive advantage, widespread casualisation may also represent an actual threat to managerial control, the weak point where the lean strategy may be attacked. In this sense, and against all expectations, it was the large number of casual workers employed by Maruti and the abuses of the contract labour system that actually triggered the crisis. Ultimately, the extensive use of contract labour, the employment of a selected workforce supposed to remain docile and not politicised, and the strenuous efforts to prevent unionisation contributed to the formation of a collective political consciousness that manifested in an unprecedented form of antagonism. In this regard, important lessons can be learned in the global struggle against casualisation, and on how solidarity can play a crucial role.

Finally, the case also shows how the emergent movement failed to acquire a proper modus vivendi, an organised subjectivity able to protect it from the degeneration of the struggle. In fact, in the absence of an adequate political and legal network giving proper resonance to the case, an event that started as an accident was eventually used by management to orchestrate the heaviest onslaught. Here, the case shows how the lean system, even when shaking, can react strongly. And it does so by seeking institutional support through the use of coercion, to the point of violently silencing dissent. In this sense, Indian industrial relations seem to have taken a dangerous turn, one which will have to be radically opposed.

Overall, despite the dramatic outcome of the case, many lessons can be learned, and the Maruti workers can still be an example for many others who are willing to fight back.

\section{REFERENCES}

All India Organisation of Employers (AIOE) (2013) Industrial Relations and Contract Labour in India. AIOE study. Available online at http://aioe.in/htm/IndustrialRelations.pdf.

Barnes, T, K.S. Lal Das and S. Pratap (2015) Labour Contractors and Global Production Networks: The Case of India's Auto Supply Chain. The Journal of Development Studies, 51(4): 355-369.

Burawoy, M. (1985) The Politics of Production - Factory Regimes Under Capitalism and Socialism, London: Verso.

Business Standard (2015) 77 Former Maruti Workers get Bail. 17 March 2015. Available online at http://www.business-standard.com/article/news-ians/77-former-maruti-workers-get-bail115031701244 1.html) [accessed 10 April 2015].

Cardoso, L.A. (2004) The Rationalized Factory and Changes in Work Management: The Case of the FIAT PostFordist Auto Plant in Brazil. In Work and Employment Relations in the Automobile Industry, edited by E. Charron and P. Stewart. Basingstoke and New York: Palgrave Macmillan.

Carter, B., A. Danford, D. Howcroft, H. Richardson, A. Smith and P. Taylor (2011) Lean and Mean in the Civil Service: The Case of Processing in HMRC. Public Money \& Management, 31(2): 115-122.

Carter, B., A. Danford, D. Howcroft, H. Richardson, A. Smith and P. Taylor (2013) "Stressed Out of My Box": Employee Experience of Lean Working and Occupational Ill-health in Clerical Work in the UK Public Sector. Work, Employment \& Society, 27(5): 747-767.

Chandrashekhar, C.P. and J. Ghosh (2014) Contract Workers in Manufacturing. Business Line, 28 April 2014.

Charron, E. and P. Stewart (2004) Introduction. In Work and Employment Relations in the Automobile Industry, edited by E. Charron and P. Stewart. Basingstoke and New York: Palgrave Macmillan.

Centro per la Riforma dello Stato (CRS) (Gruppo Lavoro) (2011) Nuova Panda schiavi in mano - La strategia FIAT 
di distruzione della forza operaia. Rome: DeriveApprodi.

Danford, A. (2004) The Social Relations of Lean Production in the British Auto-components Sector: A Case Study of Labour Subordination and Resistance. In Work and Employment Relations in the Automobile Industry, edited by E. Charron and P. Stewart. Basingstoke and New York: Palgrave Macmillan.

Danford, A., M. Richardson, V. Pulignano and P. Stewart (2008) Lean Production and Quality of Working Life on the Shop Floor: The Experience of British and Italian Car Workers. In Flexibility at Work - Critical Developments in the International Automobile Industry, edited by V. Pulignano, P. Stewart, A. Danford and M. Richardson. Basingstoke and New York: Palgrave Macmillan.

Das, K. (ed.) (2005). Industrial Clusters: Cases and Perspectives. Aldershot: Ashgate.

D'Costa A. (1995) The Restructuring of the Indian Automobile Industry: Indian State and Japanese Capital. World Development, 23(3): 485-502.

Deshpande, L.K., A.K. Karan, A.N. Sharma and S. Sarkar (2004) Liberalisation and Labour. Labour Flexibility in Indian Manufacturing. New Delhi: Institute for Human Development.

Faridabad Majdoor Samachar (FMS) (2011) From Honda to Maruti Suzuki: A Wide-Angle View of Corporate Strategies. Available online at http://faridabadmajdoorsamachar.blogspot.co.uk/2011/09/from-hondato-maruti-suzuki-wide-angle.html [accessed 15 March 2012].

Gurgaon Workers News (GWN) (Undated) Workers News from the Special Exploitation Zone (blog), Issues 41, 44 and 61. Available online at https://gurgaonworkersnews.wordpress.com.

Hindustan Times (2017) Verdict has united us say Maruti workers. Available online at http://www.hindustantimes.com/delhi/verdict-has-united-us-say-maruti-workers/storyjJgyddh6fg3DZqdgLcf]pN.html [accessed 8 April 2017.

Indian Express (2011) Face of Maruti Suzuki strike is a 24-year-old, 16 October 2011. Available online at http://indianexpress.com/article/cities/delhi/face-of-maruti-suzuki-strike-is-a-24yearold/ [accessed 12 June 2012].

IndustriALL (2015) 81 Maruti Suzuki workers granted bail, 20 March 2015. Available online at http://www.industriall-union.org/81-maruti-suzuki-workers-granted-bail [accessed 2 April 2015].

International Commission for Labor Rights (ICLR) (2013) Merchants of Menace. Repressing Workers in India's New Industrial Belt - Violation of Workers' and Trade Union Rights at Maruti Suruki India Ltd. New York: ICLR.

Ishigami, E. (2004) Competition and Corporate Strategy in the Indian Automobile Industry with Special Reference to Maruti Udyog Limited and Suzuki Motor Corporation. Paper presented at the 2004 International Conference: A Comparison of Japanese Firm and Korean Firm in Indian Automobile Market, Centre for Area Studies, Gyeongsang National University, Jinjyu, Korea, 5 November 2004.

Jha, P. and A. Chakraborty (2012) Emerging Dynamics of Global Production Networks and Labour Process: A Study from India. Available online at http://www.macroscan.org/anl/sep12/ anl120912Praveen_Amit.htm.

Jha, P. and A. Chakraborty (2014) Post-Fordism, Global Production Networks and Implications for Labour. Some Case Studies from National Capital Region, India. Working paper 2014/172 from the Institute for Studies in Industrial Development, New Delhi. Available online at http://isid.org.in/pdf/WP172.pdf.

Knorringa, P. (2005) An Italian Model and an Indian Reality: Searching for a Way Out of Deteriorating Sweatshop Conditions. In Industrial Clusters: Cases and Perspectives, edited by K. Das. Aldershot: Ashgate.

Landy F. and B. Chaudhuri (2004) Globalisation and Local Development in India. Manohar: New Delhi.

Moody, K. (1997) Workers in a Lean World - Unions in the International Economy. London: Verso.

Narayanan, G.B. and P. Vashisht (2008) Determinants of Competitiveness of the Indian Auto Industry. Working Paper n. 201. New Delhi: Indian Council for Research on International Economic Relations (ICRIER). Available online at http://www.icrier.org/pdf/working\%20paper\%20201_final.pdf.

Papola, T.S. (2013). Role of Labour Regulation and Reforms in India. ILO Employment Working Paper n. 147. Available online at http://www.ilo.org/wcmsp5/groups/public/---ed_emp/---ifp_skills/ documents/ publication/wcms_232497.pdf.

Peoples Union for Democratic Rights (PUDR) (2013) Labour Struggles and Violation of Rights in Maruti Suzuki India Limited. Delhi: PUDR.

Pries, L. (2004) New Production Systems and Workers' Participation: A Contradiction? Some Lessons from German Automobile Companies. In Work and Employment Relations in the Automobile Industry, edited by E. 
Charron and P. Stewart. Basingstoke and New York: Palgrave Macmillan.

Pulignano, V. and P. Stewart (2008) Bureaucracy Transcended? New Patterns of Employment Regulations and Labour Control in the International Automotive Industry. In Flexibility at Work - Critical Developments in the International Automobile Industry, edited by V. Pulignano, P. Stewart, A. Danford and M. Richardson. Basingstoke and New York: Palgrave Macmillan.

Pulignano, V., P. Stewart, A. Danford and M. Richardson (eds) (2008) Flexibility at Work - Critical Developments in the International Automobile Industry. Basingstoke and New York: Palgrave Macmillan.

Stewart, P., W. Lewchuk, C. Yates, M. Saruta and A. Danford (2004) Patterns of Labour Control and the Erosion of Labour Standards: Towards an International Study of the Quality of Working Life in the Automobile Industry (Canada, Japan and the UK). In Work and Employment Relations in the Automobile Industry, edited by E. Charron and P. Stewart. Basingstoke and New York: Palgrave Macmillan.

Stewart, P., M. Richardson, A. Danford, K. Murphy, T. Richardson and V. Wass (2009) We Sell Our Time No More: Workers' Struggles Against Lean Production in the British Car Industry. London: Pluto.

Tewari, M. (2008) Varieties of Global Integration: Navigating Institutional Legacies and Global Networks in India's Garment Industry. Competition \& Change, 12(1): 49-67.

Times of India (2017) Maruti Plant Violence. Available online at http://timesofindia.indiatimes.com/city/gurgaon/maruti-plant-violence-31-workers-found-guilty-13-ofmurdering-gm/articleshow/57583720.cms [accessed 8 April 2017].

Womack, J., D. Jones and D. Roos (1990) The Machine that Changed the World. New York: Macmillan.

Youth Kiawaaz (2017) Maruti incident judgment. Available online at https://www.youthkiawaaz.com/2017/03/maruti-incident-judgment-workers/ [accessed 8 april 2017].

\section{ACKNOWLEDGEMENTS}

I would like to thank Dr Satoshi Miyamura and Prof. Paul Stewart for their insightful, valuable feedback on the thesis chapters that merged into this article; and Dr Alessandra Mezzadri for her careful, tireless assistance throughout all stages of the present research, and for her helpful comments on the first drafts of this paper.

\section{BIOGRAPHICAL NOTE}

Lorenza Monaco holds an MA in Development Politics from the University of Naples "L'Orientale", Italy, and a $\mathrm{PhD}$ in Development Studies from the School of Oriental and African Studies (SOAS), University of London, UK. At SOAS, she also worked as a Teaching Fellow in Political Economy of Development. From her MA to her $\mathrm{PhD}$ her research focused on Casualisation, Labour Organising and Institutions within the Indian Automobile Industry, based on fieldwork conducted in Delhi / National Capital Region (NCR) in 2009, 2011 and 2012. She is currently a Postdoctoral Research Fellow at the South African Research Chair in Industrial Development, University of Johannesburg, where she is working on a comparative research project on the impact of auto policies on employment in India and South Africa. [Email: 1monaco@uj.ac.za] 